\title{
Ampulla of Vater Cancer pT1a TNM Finding v8
}

National Cancer Institute

\section{Source}

National Cancer Institute. Ampulla of Vater Cancer pT 1a TNM Finding v8. NCI Thesaurus.

Code C134850.

Ampulla of Vater cancer with tumor limited to ampulla of Vater or sphincter of Oddi.

(from AJCC 8th Ed.) 